JOSE IBIETATORREMENDIA†

In October 1983, facing immense capital flight and growing political unrest, ${ }^{1}$ the Philippine government imposed exchange controls $^{2}$ on Eurodollar deposits ${ }^{3}$ held in banks located in the Philippines. The controls required banks to seek government approval for any capital outflows. ${ }^{4}$ Similar concerns had led the government of Mexico to impose controls on Eurodollar deposits held in its banks in August 1982.5 So called "Mexdollar" deposits

† B.S. in Econ. 1990, University of Pennsylvania; J.D. Candidate 1993, University of Pennsylvania. This Comment was originally written as a paper for a seminar taught by Profs. Friedrich Kübler and Richard J. Herring. I thank them for their help in its creation. This Comment is dedicated to my father, who inspired me to study law, and to my mother, who made it possible.

1 Rumors of capital controls in June of 1983 triggered a massive capital outflow from the Philippines, which was accelerated by the assassination of opposition leader Benigno Aquino on August 21. See Citibank Move In Philippines Debated, AM. BANRER, Jan. 20, 1984, at 2, 2; see also infra notes $79-80$ and accompanying text. Capital controls are government restrictions on the flow of investment funds into and out of a country. See Frederic S. MISHKIN, THE Economics of MONEY, BANKING, AND FINANCIAL MARKETS 496 (3d ed. 1992). Any investment subject to such controls can lose most if not all of its liquidity. See infra note 40 and accompanying text (discussing loss of liquidity). It is interesting to note that the deposits placed by Wells Fargo Asia Ltd. with Citibank Manila were made in June of 1983, just when unrest was growing in the Philippines. See infra note 76 and accompanying text.

2 Exchange controls are government regulations directed at managing foreign exchange and controlling the flow of a country's local currency as well as its foreign exchange holdings. See Nicholas L. DEAK \& JOANNe CeluSAK, InTERNATIONAL BANRING 159 (1984). Although they do not necessarily deprive a holder of foreign exchange of her property, controls do severely hamper accessibility, resulting in a diminution in value. The situation is comparable to a depositor holding an account in a bank that has temporarily shut its doors. The knowledge that the deposit still exists is little consolation to the depositor who cannot access that deposit.

${ }^{3}$ A Eurodollar deposit is a deposit denominated in U.S. dollars held by a bank located outside of the United States. See J. ORLIN GRABBE, INTERNATIONAL FINANCIAL MARKETS 14 (2d ed. 1991). While any currency could be a "Euro" currency, the only requirement being that it is held outside of the issuing country, the market is dominated by the dollar. See id. at 15 (listing the market share of the dollar as 60\% of the Eurocurrency market).

${ }^{4}$ See Wells Fargo Asia Ltd. v. Citibank, N.A., 612 F. Supp. 351, $354-55$ (S.D.N.Y. 1985) [hereinafter WFAL ]. In contrast to the controls imposed in the Mexican cases, see infra text accompanying notes 116-18, the Philippine controls were targeted at interbank deposits. See infra text accompanying note 80.

${ }^{5}$ See Braka v. Bancomer, S.A., 589 F. Supp. 1465, 1467 (S.D.N.Y. 1984), affd, 762 F.2d 222 (2d Cir. 1985) (discussing government response to severe pressure on the Mexican peso in foreign exchange markets); see also Alan Riding, Crisis in Mexico Costs 
could only be withdrawn in pesos, at an exchange rate pegged approximately thirty percent lower than the prevailing market exchange rate. ${ }^{6}$ In both countries, depositors faced a sudden loss of assets or, at the least, greatly reduced access to their funds.

Controls such as these are internationally accepted as a method of economic self-preservation. ${ }^{7}$ In fact, most countries of the world have some sort of exchange control. ${ }^{8}$ Usually, such controls are part of a country's business environment, taken into account when foreign investors contemplate investing in the country. The sudden imposition of new controls, while not as drastic a step as expropriation, ${ }^{9}$ can wreak havoc on individuals and institutions holding

Investors in U.S. Millions, N.Y. TIMES, Aug. 24, 1982, at A1 (discussing loss to American investors in Mexican instruments as a result of the exchange controls). For a discussion of the specifics of the Mexican exchange controls, see Fernando A. Vázquez Pando, Legal Aspects of Mexican Exchange Controls, 18 INT'L LAW. 309, 311-21 (1984); Stephen Zamora, Peso-Dollar Economics and the Imposition of Foreign Exchange Controls in Mexico, 32 AM. J. CoMP. L. 99, 105-13 (1984). Zamora also discusses the more liberal controls imposed in December 1982. See id. at 115-20.

${ }^{6}$ See Riding, supra note 5, at A1. Subsequently, the gap widened as the Mexican peso dropped further in value relative to the dollar. See Callejo v. Bancomer, S.A., 764 F.2d 1101, 1106 n.2 (5th Cir. 1985) (noting that the market exchange value of the peso fell from 114 pesos to the dollar in August 1982 to 130 in November 1982).

7 The Callejo court cited the Restatement with approval:

"[T]he application to an alien of a requirement that foreign funds held within the territory of the state be surrendered against payment in local currency at the official rate of exchange is not wrongful under international law, even though the currency is less valuable on the free market than the foreign funds surrendered."

Callejo, 764 F.2d at 1117 n.21 (quoting Restatement (SECOND) OF ForeicN RELATIONS LAW OF THE UNTTED STATES $\S 198 \mathrm{cmt}$. b (1965)).

${ }^{8}$ See, e.g., InTERnational Monetary Fund, EXchange ARRANGEMENTS aNd EXCHANGE RESTRICTIONS: ANNUAL REPORT 1991, at 580-85 (1991) (listing over 120 countries with some type of exchange control). Countries with controls run the gamut from industrialized, to industrializing, to third-world. See, e.g., William F. Atkin, The Recent Liberalization of Exchange Controls and Its Legal Impact on Doing Business in Taiwan, 1988 B.Y.U. L. REV. 591, 593-97 (discussing exchange controls in Taiwan); Orlando A. Gonzáles-Arias, Spain Liberalizes Its Exchange Control Laws, 21 INT'L LAW. 1199, 1200-04 (1987) (discussing exchange controls in Spain); B.L. Ngenda, An Overview of Zambia's Exchange Control Laws, 18 INT'L'BUs. LAW. 327, 32729 (1990) (discussing exchange controls in Zambia).

${ }^{9}$ Expropriation is the forcible seizure by a government of assets from an entity under its jurisdiction. See M. Ann Hannigan, Note, United States Home Bank Liability for Foreign Branch Deposits, 1989 U. ILL. L. REV. 735, 735 n.3. When the entity is a bank, it is usually accompanied by the freezing, if not the outright repudiation, of deposits. See id.; see also, e.g., Vishipco Line v. Chase Manhattan Bank, N.A., 660 F.2d 854-56 (2d Cir. 1981) (involving the expropriation of Chase Manhattan's Saigon branch by North Vietnam), cert. denied, 459 U.S. 976 (1982); Edelmann v. Chase Manhattan Bank, N.A., 668 F. Supp. 99, 100-01 (D.P.R. 1987) (involving the 
funds in a country, as well as create instability in global monetary markets.

It is this "sovereign risk, ${ }^{10}$ the risk that government action will impede the repatriation of funds held in Eurodollar accounts, that is the subject of this Comment. Once such action has been taken, courts must determine which party, the depositor or the bank, will bear the loss. This Comment examines situs, the current method courts use to "locate" a deposit, which in turn drives the determination of which party will lose. Arguing that this approach is flawed, given the realities of the Eurodollar market, the Comment proposes a method of allocating such a loss based on economic analysis.

Part I examines the distinctive characteristics of the Eurodollar market. This is followed by a discussion of the current law of debt situs, and a critique of its application in the context of Eurodollars. ${ }^{11}$ After examining some of the litigation spawned by the Philippine $^{12}$ and Mexican ${ }^{13}$ exchange controls, as well as applicable law and economics principles, ${ }^{14}$ this Comment discusses the

expropriation by the Cuban government of Chase Manhattan's branch deposits in Cuba), rev'd and remanded, 861 F.2d 1291, 1291 (1st Cir. 1988).

${ }^{10}$ While sovereign risk more accurately describes the risk of loss when lending to a foreign government, see PANCRAS J. NAGY, CoUNTRY RISK I (1984), it will be used in this paper as it comports with the language used in the Wells Fargo litigation. See WFAL I, 612 F. Supp. 351, 353 (S.D.N.Y. 1985); see also Jote Kassa, Note, A Safety Net for the Eurodollar Market?: Wells Fargo Asia Ltd. v. Citibank, 65 N.Y.U. L. REV. 126, $129 \mathrm{n.24}(1990)$ ("Sovereign risk is narrowly defined as the risk of loss when lending to a foreign government. ${ }^{\eta}$ ). The more accurate term to describe the risk in crossborder monetary transactions presented by government action is "country risk." See NAGY, supra, at 2.

11 See infra part II. The importance of situs determination cannot be overemphasized. Under current law, the situs of a debt determines the substantive law that is applicable to disputes concerning that debt. Consequently, the outcome of the choice-of-law analysis will often prove to be the determinative issue in litigation over debt "located" in a foreign country. See, e.g., Noyes Leech, International Banking. Effects of Nationalizations and Exchange Controls, $8 \mathrm{~J}$. COMP. BUS. \& CAP. MARKET L. 123, 128 (1986) ("The trouble with reasoning on the basis of situs . . . is that once a situs is determined, the conclusion has been stated.").

12 See WFAL I, 612 F. Supp. 351 (S.D.N.Y. 1985), further proceeding, 660 F. Supp. 946 (S.D.N.Y. 1987) [hereinafter WFAL II], remanded without opinion, 847 F.2d 837 (2d Cir.) [hereinafter WFAL III], on remand, 695 F. Supp. 1450 (S.D.N.Y.) [hereinafter WFAL IV], affd, 852 F.2d 657 (2d Cir. 1988) [hereinafter WFAL V], vacated and remanded, 495 U.S. 660 (1990) [hereinafter WFAL VI], affd, 936 F.2d 723 (2d Cir. 1991) [hereinafter WFAL VII], cert. denied, 112 S. Ct. 2990 (1992). For a discussion of the Wells Fargo litigation, see infra part III.A.

${ }^{13}$ See Callejo v. Bancomer, S.A., 764 F.2d 1101 (5th Cir. 1985); Braka v. Bancomer, S.A., 589 F. Supp. 1465 (S.D.N.Y. 1984), affd, 762 F.2d 222 (2d Cir. 1985). For a discussion of these cases, see infra part III.B.

14 See infra part IV.A-C. For a general introduction to the law and economics 
allocation of sovereign risk between depositors and financial institutions and attempts to develop a rule of general application. ${ }^{15}$ This Comment concludes that, absent an explicit waiver within a deposit agreement, courts should allocate the sovereign risk to the banks. ${ }^{16}$ This allocation will promote the predictability needed for international commercial transactions, as well as provide an equitable result for relatively unsophisticated market participants. ${ }^{17}$

field, see A. MITCHELL POLINSKY, AN INTRODUCTION TO LAW AND ECONOMICS (1989); Richard A. POSNER, ECONOMIC ANALYSIS OF LAW (3d ed. 1986). Briefly, law and economics is the application of economic theory to the legal system. See id. at 19. The analysis employed is of the normative type, which seeks to find the economically correct rule, rather than positive, which merely explains the economic rationale behind existing legal rules. See id. at 21. The law and economics approach is not without its detractors. For a brief review of various critiques, including Neo-Marxist and feminist, see Robin PaUl Malloy, LAW aNd Economics: A Comparative APPROACH TO THEORY AND PRACTICE 60-101 (1990).

${ }^{15}$ See infra part IV.D.

${ }^{16}$ See infra notes $156-58$ and accompanying text. For a contrary position, see Rachel R. Gerstenhaber, Comment, Freezer Burn: United States Extraterritorial Freeze Orders and the Case for Efficient Rish Allocation, 140 U. PA. L. REv. 2333, 2372 (1992) (arguing that the risk of extraterritorial freeze orders be placed on depositors); Kassa, supra note 10, at 163 (arguing that a right of investors to repayment in U.S. dollars has two consequences besides "home office liability": it decreases the competitiveness of foreign branches and provides the safety of the American banking system "to a Eurodollar investor who has received favorable returns by passing the regulatory scheme"); Marvin J. Miller, Jr., Note, Holding U.S. Bank Home Offices Liable for Deposits in Their Foreign Branches, 11 FORDHAM INT'L L.J. 621, 637-40 (1990) (arguing that a U.S. bank home office should not be held liable in the absence of a prior arrangement between a depositor and the home office).

${ }_{17}$ Defining who is an "unsophisticated" participant in the Eurodollar market is difficult. It would defy reason to describe Wells Fargo Asia Ltd. as unsophisticated. Around the time that the Philippines was imposing its exchange controls, Wells Fargo Bank, the parent of WFAL, was the eleventh largest bank in the United States. See Second Large Bank Cuts Its Prime, N.Y. TIMES, Sept. 27, 1984, at D18 (describing Wells Fargo Bank, with $\$ 26.8$ billion in assets, as the 11 th largest bank in the United States).

However, the level of sophistication of the individual investors in Braka and Callejo, see infra notes 108-25, is not quite so self-evident. Though the amounts involved were relatively large, $\$ 2.1$ million and $\$ 300,000$ respectively, see infra note 112 , it does not follow that the individual depositors were sophisticated Euromarket participants. In certain situations, wealth may be a proxy for sophistication. See, e.g., 17 C.F.R. $\$ 230.501(a)(5)$ (1992) (categorizing individuals with a net worth of one million dollars or more as "accredited investors," sophisticated enough to purchase securities sold without registration). Given the nature of the Eurodollar market, see infra part I, it is unlikely that mere wealth will serve as an indicia of sophistication. 


\section{THE EURODOLLAR MARKET}

The modern Eurodollar market was created in 1956, during the Suez crisis, ${ }^{18}$ when British banks, faced with stiff exchange controls on British sterling, began to accept dollar deposits in order to engage in trade finance. ${ }^{19}$ The crisis ended shortly thereafter, but the practice of accepting dollar deposits did not, and expanded into other currencies. ${ }^{20}$ Thereafter, the Eurocurrency market grew rapidly, reaching a size of $\$ 4500$ billion by $1988 .{ }^{21}$ Approximately sixty percent of this market was in dollar deposits. ${ }^{22}$

The Eurocurrency market is dominated by financial institutionsit is estimated that about sixty percent of the volume is attributable to transactions between banks. ${ }^{23}$ These "interbank" transactions

${ }^{18}$ See GraBBE, supra note 3, at 16. Prior to the crisis, the Soviet Union had used Eurodollar accounts in London to shield its dollar holdings from potential U.S. action. See DeAr \& CELUSAR, supra note 2, at 167. The Soviets had feared that Cold War tensions might lead to a United States freeze of Soviet dollar holdings in New York. See GRABBE, supra note 3, at 17. This fear was not unwarranted, as the United States has, on occasion, attempted to advance its foreign policy through the freezing of Eurodollar deposits. See, e.g., Libyan Arab Foreign Bank v. Bankers Trust Co., [1988] 1 Lloyd's Rep. 259 (Q.B.) (involving litigation arising from the U.S. freeze order directed against all Libyan assets held abroad by U.S. entities).

The cost of U.S. banking regulation also spurred the development of the Eurodollar market. See infra notes $30-38$ and accompanying text. For a broad historical examination of the Eurodollar market, see generally W.P. HOGAN \& I.F. PEARCE, THE INCREdible EURODOLlaR 12-87 (1982); JANE S. LITTLE, EUROdOlLARS: THE MONEY-MARKET GYPSIES (1975); EUGENE SARVER, THE EUROCURRENCY MARKET HANDBOOR 27-66 (2d ed. 1990).

19 See GRABBE, supra note 3, at 17. Such financing involves the extension of credit to an importer in a foreign country purchasing goods from a third country. See SARVER, supra note 18, at 31. Before the crisis, British banks had used British sterling to finance external trade loans. See GRABBE, supra note 3, at 16. Dollars are well suited to such financing due to their ready acceptance. See JOHN C. POOL \& STEVE STAMOS, THE ABCs OF INTERNATIONAL FINANCE 44-46 (1987) (describing the rise of the dollar standard and the resulting widespread acceptability of the dollar).

${ }^{20}$ Markets are currently active for most of the world's major currencies, including Deutschemarks, yen, and pounds sterling. See SARVER, supra note 18, at 277-325 (discussing the Euromarkets in the three currencies mentioned, as well as nine others).

21 See Peter S. Smedresman \& Andreas F. Lowenfeld, Eurodollars, Multinational Banks, and National Laws, 64 N.Y.U. L. REV. 733, 743-44 (1989).

22 See supra note 3.

23 See Anthony Saunders, The Eurocurrency Interbank Market: Potential for International Crises?, FED. RESERVE BANK PHILA. BUS. REV., Jan.-Feb. 1988, at 17, 17-18; see also BANK FOR INT'L SETTLEMENTS, THE INTERNATIONAL INTERBANK MARKET: A DESCRIPTIVE STUDY 22-23 (1983) (describing the interbank portion of the Eurodollar market as ranging between $63 \%-78 \%$ during the years 1975 to 1981). The transaction at issue in the Wells Fargo litigation was an interbank transaction. See infra notes 7677 and accompanying text. 
are usually for $\$ 1$ million or more, and have a short duration, ranging from overnight to six months. These deposits play a crucial role in maintaining bank liquidity ${ }^{24}$ and keeping interest rates in line with supply and demand. ${ }^{25}$

The other forty percent of the market is composed of endborrowers and lenders, the entities that borrow and deposit funds. An example of a Eurodollar transaction is illustrative of the market structure. Bank A, resident in London, takes a U.S. dollar deposit from Corporation $B$, also a London resident. Later that same day, Bank $A$ decides to deposit the funds in an overnight account with Bank C, based in Singapore. Still later, Bank C makes a dollar loan to Corporation D, located in Thailand. ${ }^{26}$ The net effect of this series of transfers is a transfer of funds from Corporation $B$ to Corporation D.

This net transfer is accomplished by the transfer of funds between the New York Federal Reserve accounts of Corporation B's and Corporation D's banks. ${ }^{27}$ The interbank transaction between

${ }^{24}$ A bank with an imbalance between deposits and loans can turn to the interbank market to correct the mismatch. See DEAK \& CELUSAK, supra note 2, at 169 . The balance between assets and liabilities is reflective of a bank's liquidity, its ability to convert its assets (e.g., mortgages, commercial loans) into cash that can be used to cover the bank's liabilities (e.g., deposits). See MiSHKIN, supra note 1, at 24, 206-07.

${ }^{25}$ See BANK FOR INTERNATIONAL SETTLEMENTS, supra note 23, at 10; DEAK \& CeluSAK, supra note 2, at 169 . The interbank system also allows banks to hedge foreign exchange positions, as well as balance their accounts when more funds are needed to support their loans. See Saunders, supra note 23, at 18.

${ }^{26}$ For purposes of this example, the assumption is made that the amount received by Bank $C$ is loaned out in its entirety to Corporation $D$. This simplifies reality in two ways. First, a bank will usually keep a portion of each deposit as a reserve against the loans it has outstanding. Such a reserve may be required by statute or may merely be suggested by prudence. See infra notes 33-35 and accompanying text (discussing Regulation $D$ reserve requirements).

The example also fails to deal with the money creation that accompanies the depositing of funds in a bank. If each bank in a given banking system keeps $10 \%$ of every deposit as a reserve, lending out the other $90 \%$, the system as a whole will be able to make loans equal to ten times the original deposit, a phenomenon known as multiple deposit creation. See MISHKIN, supra note 1, at 324-30. This assumes, of course, that loan recipients continue to deposit their loan proceeds in the system. If the cash sits in someone's mattress, no further expansion is possible. Estimates of the actual multiplier, the amount of credit created by a deposit in the Eurodollar market, range from .37 to 18. See Hal S. Scott, Where Are the Dollars?: Off-Shore Funds Transfers, 3 BANKING \& FIN. L. REV. 243, 285 (1989).

27 This transfer of funds between reserve accounts is known as settlement, the closing out of outstanding positions between banks. The usual mechanism for Eurodollar market participants is the Clearing House Interbank Payments System ("CHIPS") in New York. See DARA M. KhaMbata, THE PRACTICE OF Multinational. BANRING 153 (1986); Smedresman \& Lowenfeld, stupra note 21, at 745; Herbert F. 
banks $A$ and $C$ is only recorded on paper, or, more likely, on a computer. The only "real" money exchanged is the transfer from B's bank to D's bank.

A distinguishing feature of the Eurocurrency market is its relative freedom from regulation ${ }^{28}$ because of its existence, by definition, outside of the jurisdiction of the country issuing the currency. ${ }^{29}$ In the case of dollars, the advantages can be significant. In the late sixties, the Federal Reserve's Regulation $\mathbf{Q}^{30}$

Lingl, Comment, Risk Allocation in International Interbank Electronic Fund Transfers: CHIPS E⿱ SWIFT, 22 HARV. INT'L L.J. 621, 626 (1981) (noting that CHIPS clears "approximately 90 percent of all international interbank dollar transactions"). For a judicial discussion of CHIPS, see WFAL VI, 495 U.S. at 663. CHIPS has over 130 participants, engaging on average in over 140,000 transactions a day, with a typical daily volume of over $\$ 800$ billion. See SARVER, supra note 18 , at 337 .

The member institutions of CHIPS can be divided between settling and nonsettling participants. At the end of the business day, each non-settling bank calculates its position vis-a-vis its settling partner, one of 20 such settling banks. See id. The settling banks then settle among each other, with any necessary transfer effected by shifting funds from one bank's Federal Reserve account to the other bank's Federal Reserve account. See id.; Smedresman \& Lowenfeld, supra note 21, at 745. Banks that are not members of CHIPS, or of Fedwire, the Federal Reserve's settlement system for member banks, have a correspondent bank, which is a member,to settle their transactions. See KHAMBATA, supra, at 153. The settlement process is graphically represented in Scott, supra note 26, at 261.

${ }^{28}$ See WILLIAM H. BAUGHN \& DONALD R. MANDICH, THE INTERNATIONAL BANKING HANDBOOK 25-26 (1983).

${ }^{29}$ See id. at 26 . For an overview of U.S. regulations affecting international banking, see KHAMBATA, supra note 27, at 35-44 (reviewing the substance and underlying principles of regulatory legislation in the United States); Marilyn B. Cane \& David A. Barclay, Competitive Inequality: American Banking in the International Arena, 13 B.C. INT'L \& COMP. L. REV. 273, 275-88 (1990) (reviewing U.S. regulations on foreign branches of U.S. banks); see also Pierre-Bruno Ruffini, Multinational Banking and Regulation: An Economist's Point of View, 5 J. COMP. BUS. \& CAP. MARKET L. 3, 16-20 (1983) (analyzing attempts to regulate the Eurodollar market in economic terms); $c f$. ORGANISATION FOR ECONOMIC CO-OPERATION \& DEV., REGULATIONS AFFECTING INTERNATIONAL BANRING OPERATIONS OF BANKS AND NON-BANKS (1981) (describing banking regulations in Belgium, Luxembourg, France, Germany, the Netherlands, Sweden, Switzerland, and the United Kingdom); Cane \& Barclay, supra, at 289-315 (reviewing regulation of foreign bank branches by Japan, the United Kingdom, and Germany); Brigid Gavin, A GATT for Intermational Banking!, $19 \mathrm{~J}$. WORLD TRADE L. $121,134-35$ (1985) (advocating greater international coordination in regulating international banking, with the treaties concerning trade as a model). Of course, a Eurocurrency market could be stifled if a government so desired. Without international capital flow and relatively free exchange regulations, a Eurocurrency market would collapse. See Ruffini, supra, at 9.

${ }^{30}$ Regulation $Q$ governing interest paid on deposits, is presently codified at 12 C.F.R. \$ 217.1-.6 (1992). In the late sixties, Regulation $Q$ provided for an interest ceiling on deposits. At present, interest rates are not capped-Regulation $Q$ merely prohibits the payment of interest on demand deposits. See id. $\$ 217.1(\mathrm{~b})$. 
placed a limit on the amount of interest U.S. banks could pay on deposits. As market interest rates rose past the Regulation $Q$ levels, money was shifted from deposit accounts to Treasury bills and commercial paper. ${ }^{31}$ Foreign banks accepting Eurodeposits, as well as the similarly situated overseas branches of U.S. banks, were able to offer higher rates, thereby maintaining their deposit bases. $^{32}$

Eurodollar accounts are also not subject to U.S. Regulation $\mathrm{D}^{33}$ reserve requirements. ${ }^{34}$ Banks holding these deposits can relend as much of the funds as they desire. ${ }^{35}$ Furthermore, Eurodeposits are free of deposit insurance premiums, which are required on the first $\$ 100,000$ deposited in any U.S. account. ${ }^{36}$ Eurodollar loans also have lower overhead and personnel costs, ${ }^{37}$ allowing banks accepting Eurodollar deposits to offer a higher rate of return to its depositors. ${ }^{38}$ Increased income arising from these lower costs is shared with depositors as well as borrowers.

Another component of the higher rate of return to Eurodepositors is undoubtedly a risk premium. This premium seeks to compensate for the greater risk associated with keeping money in a foreign country. ${ }^{39}$ Unlike accounts held within the country

${ }^{31}$ See GrABBE, supra note 3, at 17.

32 See id.

${ }^{33}$ See Reserve Requirements of Depository Institutions, 12 C.F.R. \$§ 204.1-.9, 204.121-.132 (1992).

${ }^{34}$ See 12 U.S.C. $\$ 461(b)(6)$ (1988). The Federal Reserve has interpreted this exemption as applying to deposits payable only at an office outside the United Statesany deposit guaranteed by a domestic office must meet the reserve requirements. See 12 C.F.R. $\$ 204.128(b)$, (d) (1992). For a U.S. resident to hold a deposit that is only payable abroad, the deposit must be at least $\$ 100,000$. See id. $\S 204.2(t)$. There is no minimum amount required for non-U.S. residents. See id.

In the late seventies, the United States advanced a proposal to require banks dealing in Eurodollars to hold minimum reserves. See Ruffini, supra note 29, at 17. Following opposition by international financial centers, and the realization that this type of regulation would merely shift the markets to countries that did not observe such agreements, the proposal was dropped. See id. at 18.

${ }^{35}$ Regardless of the regulation, a bank may feel that an informal reserve is a prudent precaution.

${ }^{36}$ See Federal Deposit Insurance Corporation Act, 12 U.S.C. § 1821(a) (1988) (creating a Permanent Insurance Fund for insuring deposits in an amount up to $\$ 100,000)$. Federal Reserve regulations specifically exempt deposits which are only repayable abroad. See 12 C.F.R. \& 330.3(e) (1992).

${ }^{3}$ See SEung H. KIM \& STEPHen W. Miller, Competrtive Structure of THE INTERNATIONAL BANKING INDUSTRY 18 (1983).

${ }^{38}$ See Smedresman \& Lowenfeld, supra note 21 , at 744 .

${ }^{39}$ A risk premium is the additional return required by an investor who is assuming a risk. See RICHARD A. BREALEY \& STEWART C. MYERS, PRINCIPLES OF 
issuing the currency, foreign governments can and do take action against Eurocurrency accounts. When a country imposes exchange controls, ${ }^{40}$ the liquidity of a Eurodeposit is reduced to nil.

CORPORATE FINANCE 161-62 (4th ed. 1991). This premium is taken into account in setting the interest rate payable on the deposit. See Ian H. Giddy, Eurocurrency Interest Rates and Their Linkages, in 1 INTERNATIONAL FINANCE HANDBOOK § 3.3, at 3, 11 (Abraham M. George \& Ian H. Giddy eds., 1983). Return will be positively correlated with risk; the riskier an asset is, the greater the required return. This is one of the basic premises of the capital asset pricing model, which seeks to determine the price of an asset by calculating how much of a risk premium the asset should pay over and above the risk-free rate. See BREALEY \& MYERS, supra, at 162. A risk premium should be evident in any investment that is not risk free, with the standard definition of risk free being short-term U.S. government debt. See id. at 161. The use of U.S. government notes is strictly pragmatic-if the United States ever defaults, there will be more things to worry about than risk-return ratios.

Whether this risk premium exists in Eurodollar interest rates is debatable. Witness the behavior of Citibank in the Wells Fargo litigation. At the time Wells Fargo placed its deposit, Citibank was offering the same rate to depositors in Manila as it was to depositors in London. See WFAL II, 660 F. Supp. at 950; see also Saunders, supra note 23, at 21-22 (discussing the results of a study intimating that spreads were too narrow to account for a risk premium). If there is no difference between London and Manila interest rates, it is difficult to argue that a risk premium is a component of the rates. But see infra note $\mathbf{8 7}$ (discussing an alternative reason for the equality in interest rates).

${ }^{10} \mathrm{~A}$ country might impose controls for numerous reasons. The most common include responding to a short-term fiscal crisis or implementing an economic development plan. See DEAK \& CELUSAK, supra note 2, at 159-60; see also CoURTNEY Blackman, Managing Foreign Exchange Reserves in Small Developing COUNTRIES 1-16 (1982) (discussing the necessity of controls in maintaining a developing country's foreign exchange reserves).

The Mexican exchange controls of 1982 are a paradigmatic example of controls implemented in the midst of an exchange crisis. See BUSINESS INT'L CORP., GUIDE TO ExchaNce CoNTROLS IN 25 CoUNTRIES 62-63 (1982). The government of Mexico, which earned most of its foreign exchange from the sale of oil, was faced with falling oil prices in mid-1982, placing a severe strain on its ability to generate foreign exchange. See Braka v. Bancomer, S.A., 589 F. Supp. 1465, 1467 (S.D.N.Y. 1984), affd, 762 F.2d 222 (2d Cir. 1985). The controls imposed in early September designated a two-tier exchange rate, including mandatory conversion of Eurodeposits held by nonresidents at the ordinary rate, resulting in an immediate loss of approximately $30 \%$ of a Eurodollar deposit's value. See id. at 62,67 ; Riding, supra note 5, at Al (reporting that Americans have lost "hundreds of millions of dollars" as a result of Mexican exchange controls); see also Callejo v. Bancomer, S.A., 764 F.2d 1101,1104 (5th Cir. 1985) (characterizing the regulations as "a Montezuma's revenge on American investors who had dollar deposits in Mexican banks").

Any windfall to a depository institution was quickly confiscated by the Mexican government when it nationalized local commercial banks shortly after the new exchange controls were declared. See id. at 1106. This bank nationalization, coming hard on the heels of the devaluation, sounds suspiciously like an expropriationMexico acquired dollars at a rate lower than the market rate. The International Monetary Fund, however, ruled that the Mexican controls were valid exchange controls. See id. at 1119; see also Joseph Gold, "Exchange Contracts, "Exchange Control, 
Another risk in maintaining a Eurocurrency account is the question of central bank intervention, or lack thereof. While a central bank would aid a domestic branch caught in a liquidity crunch, it is questionable whether it would do the same if the crunch was precipitated in the bank's foreign branches. ${ }^{41}$ Thus, a Eurocurrency depositor may be faced with a greater risk of bank failure since the bank taking the Eurocurrency deposit may not be "backed up" by a country's central bank.

This freedom from costs imposed in the United States, plus the added risks, will result in a narrower spread between the rate banks will pay on deposits and the rates they will charge borrowers. ${ }^{42}$ This narrower spread is imposed by arbitrage principles-the numerous investors and borrowers in the market will take advantage of any pricing discrepancy up to the point at which the discrepancy no longer exists. ${ }^{43}$ Consequently, profit margins in the Eurocurrency markets are narrower, making it a high-volume business. ${ }^{44}$

To summarize, the Eurocurrency market can be characterized as a broad, fast-moving, virtually unregulated market. Interest rates on

and the IMF Articles of Agreement, 33 INT'L \& CoMP. L.Q. 777, 781-84, 789-92 (1984) (discussing section 2(b) of IMF Article VIII, which voids any exchange contract that is contrary to an IMF member's exchange controls).

In a marked reversal of policy, the Mexican government has recently begun to reprivatize the Mexican banking system. See Tom Brown, Mexico Sells a State-Owned Bank, PHILA. INQ., Oct. 29, 1991, at E9. Bancomer, the defendant bank in both Braka and Callejo, was just recently returned to private hands. See id.

For further commentary on Mexico's exchange controls vis-a-vis IMF regulations, see Stephen Zamora, Exchange Control in Mexico: A Case Study in the Application of IMF Rules, 7 Hous. J. INT'L L. 103 (1984) (reviewing the implementation of Mexican exchange controls and their relation to the International Monetary Fund Agreement).

${ }^{41}$ See Giddy, supra note 39, § 3.3, at 10; see also Ulrich Hess, The Banco Ambrosiano Collapse and the Luxury of National Lenders of Last Resort With International Responsibilities, 22 N.Y.U. J. INT'L L. \& POL. 181, 187 (1990) ("[N]o evidence exists of an international custom establishing an obligation for national lenders of last resort to pay foreign creditors of foreign subsidiaries of failed banks.").

${ }^{42}$ See Smedresman \& Lowenfeld, supra note 21, at 744. Free from the costs of regulations, banks can pay higher interest rates to depositors, as well as charge less for the loans they make. See SARVER, supra note 18, at 17-18, 24-25. Where the savings generated by lower costs ends up-with the depositor, the bank, or the borrower-is up to the market to decide.

${ }^{43}$ See SARVER, supra note 18, at 17-18; see also BANK FOR INT'L SETTLEMENTS, supra note 23 , at 10 (reviewing why non-bank depositors and borrowers might discriminate between banks).

${ }^{14}$ See BANK FOR INT'L SETTLEMENTS, supra note 23, at 14-15 (noting the low profitability of money-market operations and linking the bank success to predictions of interest rate changes); Nicolas A. Saade Jr., How Banks Can Live with Low Spreads, EUROMONEY, Nov. 1981, at 139, 139 (describing high volume of transactions in Eurocredit markets and explaining how banks cope with generally low profit margins). 
Eurocurrencies are more attractive than those in the currency's home country. Competition is strong, with thin margins providing financial institutions little cushion in their transactions. Compared to this robust market, the concept of situs is archaic, ${ }^{45}$ vainly attempting to place the ephemeral. ${ }^{46}$

\section{The Doctrine of DebT Situs}

Courts dealing with debt disputes have resorted to the concept of situs, where the debt is "located," when determining whether or not a bank is liable for a debt when litigation arises. ${ }^{47}$ The situs of the debt is often dispositive-the law of the location will apply in determining the liability between a depositor and a bank. ${ }^{48}$ Situs, in fact, acts as a choice of law mechanism. Its territorial approach has a mechanistic quality that sets it apart from the predominant choice of law method, governmental interest analysis. ${ }^{49}$ While it has been proposed that some type of interest analysis be adopted in lieu of situs, ${ }^{50}$ this Comment proposes a rule based approach,

45 The rules of situs in American law can be traced back to Justice Story's treatise on conflicts. See Robert C. Alden, Note, Modernizing the Situs Rule for Real Property Conflicts, 65 TEX. L. REV. 585, 585 \& n.1, $587-91$ (1987) (citing JOSEPH STORY, Commentaries ON THE CONFLICT OF LAWS (photo. reprint 1972) (1834), and describing the history of lex situs in the United States).

16 See Richard J. Herring, Comment, in Protectionism and InTERnational BANRING 62, 69 (Gerhard Fels \& George Sutija eds., 1991) (noting that "[t]he emphasis on situs implicitly treats a Eurodollar deposit as if it were ... some ... commodity that has an unambiguous location").

${ }^{17}$ See James A. Johnson, Note, Act of State: The Fundamental Inquiry of Situs Determination for Expropriated Intangible Property: Braka v. Bancomer, S.N.C., 11 N.C. J. INT'L L. \& COM. REG. 121, 124-25 (1986) (noting that a situs determination is essential for determining the status of intangible property). The concept of situs has attracted a substantial amount of negative commentary. See, e.g., P.J. Rogerson, The Situs of Debts in the Conflict of Laws-Illogical, Unnecessary, and Misleading, 49 CAMBRIDGE L.J. 441, 441-44, 453-60 (1990) (discussing British law); Karen L. Goldthwaite, Comment, Recent Approaches to Situs of Debt in Act of State Decisions, 1 CoNN. J. INT'L L. 151, 182-83 (1986) (proposing a "factors analysis" test for determining debt situs); Margaret E. Tahyar, Note, The Act of State Doctrine: Resolving Debt Situs Confusion, 86 ColUM. L. REv. 594, 594-611 (1986) (arguing that current debt situs rules are inadequate and advocating the "incidents of the debt" approach as more in keeping with the act of state doctrine).

18 See Leech, supra note 11, at 128.

19 See, e.g., Larry Kramer, Rethinking Choice of Law, 90 CoLUM. L. REV. 277, 278 (1990) (describing Brainerd Currie's governmental interest analysis approach as "probably ... the dominant choice of law theory among academics")

${ }^{50}$ See, e.g., H. Thomas Byron, III, Comment, A Conflict of Laws Model for Foreign Branch Deposit Cases, 58 U. CHI. L. REv, 671, 693-701 (1991) (advocating the use of interest analysis in foreign branch deposit cases); see also Alden, supra note 45 , at 619 - 
using an economic analysis that removes the choice of law question. ${ }^{51}$ The difficulties with situs are further amplified by the inconsistent statements of the doctrine used by courts that have addressed the issue. ${ }^{52}$ Unless situs has been determined via contractual agreement, ${ }^{53}$ courts have applied one of three tests: domicile, complete fruition, or incidents of the debt.

\section{A. The Domicile Test}

The domicile test, developed in Harris $v$. Balk, ${ }^{54}$ a 1905 Supreme Court debtor-creditor case, was the first situs test promulgated by American courts. Traditional jurisdictional principles allowed a state court to extend personal service to a debtor if the debtor was within the territorial jurisdiction of a state. ${ }^{55}$ The Harris Court expanded on this principle by holding that a state having jurisdiction over the debtor also acquires jurisdiction over the debt-that is, situs follows the debtor. ${ }^{56}$

In foreign branch liability litigation, the domicile test has a pernicious effect in expropriation cases. The situs of the debt when a foreign branch is expropriated remains in the foreign country, thus extinguishing the debt. ${ }^{57}$ However, if a branch closes before

20, 681-33 (arguing that lex situs in real property cases should be replaced with an explicit interest analysis).

${ }^{51}$ See infra part IV.D. The rule approach is closer to the positions of Professors Ehrenzweig and Reese. See Albert A. Ehrenzweig, A Proper Law in a Proper Forum: $A$ "Restatement" of the "Lex Fori Approach," 18 OKLA. L. REV. 340, 344 (1965) ("Our first quest is for a true rule . . . ."); Willis L.M. Reese, Choice of Law: Rules or Approach, 57 CORNELL L. REV. 315, 333 (1972) (arguing that "the formulation of rules should be as much an objective in choice of law as it is in other areas of the law").

52 This proliferation of tests has led to inconsistent results, detrimental to the smooth flow of commercial transactions. Confusion over which test to apply occurs even within the same circuit. Compare Braka v. Bancomer, S.N.C., 762 F.2d 222, 224 (2d Cir. 1985) (applying complete fruition test; holding that bank is not liable) with Vishipco Line v. Chase Manhattan Bank, N.A., 660 F.2d 854, 862 (2d Cir. 1981) (applying domicile test; holding that bank is liable).

${ }^{53}$ See, e.g., WFAL V, 852 F.2d 657, 660 (2d Cir. 1988); Allied Bank Int'l v. Banco Credito Agricola de Cartago, 757 F.2d 516, $521-22$ (2d Cir.) (considering New York to be the situs of the debt since it was designated the place of repayment), cert. dismissed, 473 U.S. 934 (1985).

54198 U.S. 215 (1905).

55 See id. at 221.

56 See id. at 222-23.

57 See Perez v. Chase Manhattan Bank, N.A., 463 N.E.2d 5, 10-11 (N.Y. 1984) (holding that since defendant bank's Cuban branches were operating at the time of their expropriation, the situs of plaintiff's deposits was Cuba). 
action is taken, the debt situs will "spring back" to the home office. ${ }^{58}$

The Second Circuit applied the domicile test in Vishipco Line $v$. Chase Manhattan Bank, N.A. ${ }^{59}$ The plaintiff purchased a certificate of deposit from defendant bank's Saigon branch in the last days of the Vietnam conflict. ${ }^{60}$ A week before Saigon fell, Chase Manhattan closed down its branch; the Vietnamese government confiscated the branch shortly thereafter. ${ }^{61}$ The court held that Chase's withdrawal from Saigon before any government action had the effect of shifting the debt's situs to New York. ${ }^{62}$ The actions by the Vietnamese government did not release Chase from its obligation to repay its depositors. ${ }^{63}$

\section{B. The Complete Fruition Test}

Under the complete fruition test, the situs of the debt depends on whether a taking came to "complete fruition within the dominion of the [foreign] government." 64 The test has two

${ }^{58}$ See Vishipco Line v. Chase Manhattan Bank, N.A., 660 F.2d 854, 863 (2d Cir. 1981) (holding that situs had "sprung back" to defendant's New York headquarters since its Saigon branch closed before any government action); Patrick Heininger, Liability of U.S. Banks for Deposits Placed in Their Foreign Branches, 11 LAW \& POL'Y INT'L BUS. 903, 975 (1979) ("[I]f the branch is closed . . . the situs of the debt ... [will] spring back and cling to the home office."). For analysis of Vishipco, see Brett R. Turner, Note, The Harvest of Sabbatino: Vishipco Line v. Chase Manhattan Bank, 8 N.C. J. INT'L L. \& COM. REG. 87 (1982) (detailing the Vishipco opinion and finding it inconsistent with the Supreme Court's interpretation of the act of state doctrine).

${ }^{59} 660$ F.2d 854 (2d Cir. 1981).

${ }^{60}$ See id. at 857 .

61 See id.

62 See id. at 862.

63 This results in a perverse incentive structure. Chase would have been better off staying in Saigon and attempting to hasten government action against its branch office. Situs would then have been in Vietnam, and the debt would presumably have been extinguished. See id. at 862-63. Any attempt to preserve assets by preempting government action, as Chase did in Vishipco, would result in the bank being fully liable. For further treatment of Vishipco, see Bernadette Celentano, Vishipco Line v. the Chase Manhattan Bank: Bank Liability for Foreign Branch Seizures, 2 ANN. REV. BANKING L. 393 (1983) (focusing on Vishipco's interpretation of home office liability under New York law).

6s Allied Bank Int'l v. Banco Credito Agricola de Cartago, 757 F.2d 516, 521 (2d Cir.) (alteration in original) (quoting Tabacalera Severiano Jorge, S.A. v. Standard Cigar Co., 392 F.2d 706, 715-16 (5th Cir.), cert. denied, 393 U.S. 924 (1968)), cert. dismissed, 473 U.S. 934 (1985). Allied Bank has been the object of commentary critical of its application of the situs test. See Harris Black, Comment, Allied Bank International v. Banco Credito Agricola de Cartago: Applying the Act of State Doctrine to Actions Against Foreign Debtors, 13 BROOK. J. INI'L L. 183, 184 (1987) (concluding 
prongs. First, the depositor and the bank must both be under the jurisdiction of the government that has acted. ${ }^{65}$ Second, the situs of the debt must be within the country taking action. ${ }^{66}$ If both these conditions are met, then situs is deemed to be in the foreign country, and that country's law controls. Otherwise, situs is held to be in the United States, and U.S. law applies.

In Braka v. Bancomer, S.N.C., ${ }^{67}$ the Second Circuit used the complete fruition test in determining the situs of a debt. The court focused on the provisions incorporated into the certificates of deposit, finding that situs of the debt was in Mexico. ${ }^{68}$ Once this determination was made, the court found that the bank was not liable. ${ }^{69}$

The flaw in the complete fruition test is obvious-it does not really resolve the situs determination question. It merely adds a second requirement, that the depositor and the bank be under the foreign sovereign's jurisdiction, to the requirement that situs be in the foreign country.

\section{The Incidents of the Debt Test}

The incidents of the debt test was formulated to more directly answer the situs question. This test looks at "where the incidents of the debt, as a whole, place it." ${ }^{\text {70 }}$ A number of factors should be considered, including where the deposit was carried, ${ }^{71}$ "the place

that complete fruition test is of little use in determining applicability of act of state doctrine); James M. Wall, Note, Allied's Flawed Application of the Act of State Doctrine: Impropriety of the Doctrine in International Finance, 20 CORNELL INT'L L.J. 253, 254 (1987) ("[T]he [Allied] court adopted an inaccurate formula of debt situs incompatible with the act of state doctrine's constitutional underpinnings.").

${ }^{65}$ See, e.g., Tabacalera, 392 F.2d at 713-16 (holding that a Florida-based corporation with no presence in Cuba was not subject to a fait accompli by the Cuban government).

${ }^{66}$ See, e.g., Allied Bank, 757 F.2d at 521-22 (concluding that situs of debt was in New York, and the requirements of the complete fruition test were not met).

67762 F.2d 222 (2d Cir. 1985), affg Braka v. Bancomer, S.A., 589 F. Supp. 1465 (S.D.N.Y. 1984).

${ }^{68}$ See id. at 224-25. For a more complete discussion of Braka, see infra notes 108 22 and accompanying text; see also Johnson, supra note 47, at 124-26 (discussing Braka and situs).

${ }^{69}$ See Braka, 762 F.2d at 225-26.

${ }^{70}$ Callejo v. Bancomer, S.A., 764 F.2d 1101, 1123 (5th Cir. 1985); see also Edelmann v. Chase Manhattan Bank, N.A., 861 F.2d 1291, 1301-02 (1st Cir. 1988) (applying elements of the incidents of the debt test in the court's choice of law analysis).

${ }^{7}$ See Vishipco Line v. Chase Manhattan Bank, N.A., 660 F.2d 854, 862 (2d Cir. 1981) (noting that the branch that has a deposit listed as a liability on its books is said 
of payment, the intent of the parties (if any) regarding the applicable law, and the involvement of the American banking system in the transaction. ${ }^{n 72}$

Unlike the complete fruition test, the incidents of the debt test does not limit itself to what the parties have contracted between themselves. If a court, after examining the incidents, finds that the interests of the foreign state outweigh those of the United States, the situs will be the foreign state, and action by that state will not be adjudicated. ${ }^{73}$ The incidents of the debt test allows a court to fully account for the interests of a foreign government, thereby avoiding any antagonism of that government.

The prevailing situs rules are ill-suited to deal with the transitory nature of the modern Eurocurrency market. ${ }^{74}$ It can hardly be said that a debt "resides" in a country when the debt merely exists as a few bytes of data in a computer database. ${ }^{75}$ Situs is a common law doctrine, and there is nothing preventing the creation of a new prudential doctrine, one more sensitive to the realities of the Eurodollar market. The shortcomings of situs, and the difficulty courts evidence in applying the doctrine, are apparent in recent cases arising from the imposition of exchange controls in the Philippines and Mexico.

to carry that deposit).

72 Callejo, 764 F.2d at 1123 . Another possible factor is the currency denomination involved. Some countries may wish to control their currencies more strictly than other countries. See Tahyar, supra note 47, at 613 (stating that "the currency denomination of the debt may be relevant to a foreign sovereign's relationship to a debt"). If such is the case, the country desiring more control may have a greater interest in having situs within its borders.

${ }^{73}$ See, e.g., Callejo, 764 F.2d at 1125 (stating that Mexico's interest in the situs of the deposits is greater than Texas's interest since the deposits were "issued by a Mexican bank and payable in Mexico"). For further discussion of Callejo, see infra notes 109-18, 123-25 and accompanying text.

This test does little, however, to promote consistency of result. Different courts will balance the factors differently. Consequently, it is difficult for parties to predict how courts will interpret their transactions ex ante.

74 For a critique of situs rules as they apply to foreign held deposits, see Byron, supra note 50, at 686-91 (stating that current situs rules are "anachronistic" because they preclude inquiry into other pertinent factors).

${ }^{75}$ The existence of an inter-office component in the Eurocurrency market complicates the equation even more. A bank can and will transfer deposits among its own branches, depending on its funding requirements in each country. See BANK FOR INT'L SETTLEMENTS, supra note 23, at 20-21 (estimating inter-office activity as accounting for $38 \%$ of the "reported interbank claims"). 


\section{THE WELLS FARgo AND MEXICAN CASES}

The limits of the territorial concept of situs are demonstrated in the Wells Fargo, Braka, and Callejo cases discussed in this section. In each, the court had to grapple with the location of a Eurodollar deposit, using the tool of situs. The opposite results reached are testament to the uncertainty under current law.

\section{A. The Wells Fargo Litigation}

In June of 1983, Wells Fargo Asia Ltd., based in Singapore, placed two six-month, $\$ 1$ million certificates of deposit ( $(\mathrm{CDs}$ ") with Citibank at its Manila branch. ${ }^{76}$ This interbank transaction was arranged by a broker, and was confirmed by the broker's telexes, as well as by the subsequent exchange of written confirmation. ${ }^{77}$ The CDs were priced to yield $10 \%$ per year as an "Asiadollar" deposit. $^{78}$

Later in 1983, the Philippines began to experience a foreign exchange crunch and investors began taking millions of dollars out of the country. ${ }^{79}$ The government responded by issuing a Memorandum to Authorized Agent Banks ("MAAB 47"), which provided: "Any remittance of foreign exchange for repayment of principal on all foreign [interbank] obligations ... shall be submitted to the Central Bank ... for prior approval. ${ }^{n 80}$

${ }^{76}$ See WFAL V, 852 F.2d 657, 658 (2d Gir. 1988). At the time, Citibank was one of only four foreign banks operating full branches in Manila. See M.S. Mendelsohn, Wells Suit Revives Jurisdiction Issue, AM. BANKER, Mar. 2, 1984, at 1, 18. Only full branches were allowed to accept Eurodollar deposits-the more than 20 other foreign banks not operating as full branches were unaffected by the ruling. See id.

77 See WFAL I, 612 F. Supp. 351, 354 (S.D.N.Y. 1985). For the full text of the telexes and the written confirmation slips, see WFAL IV, 695 F. Supp. 1450, 1452 (S.D.N.Y. 1988). Eurocurrency transactions are usually carried out in this informal manner. See John E. Hoffman, Jr. \& Rachel E. Deming, The Role of U.S. Courts in the Transnational Flow of Funds, 17 N.Y.U. J. INT'L L. \& POL. 493, 499 (1985) (stating that the "express terms of such a transaction are customarily stated in very brief communications which are made either by telex or by telephone and later confirmed by mail").

${ }^{78}$ See WFAL I, 612 F. Supp. at 352. At the time, the rate in the United States for CDs of the same duration was $8.85 \%$. See id.; see also supra notes $30-41$ and accompanying text (discussing reasons for higher rates for deposits in the Eurocurrency market). Significantly, Citibank was offering the same rate for Eurodollar deposits at all its branches worldwide. See WFAL II, 660 F. Supp. 946, 950 (S.D.N.Y. 1987).

${ }^{79}$ See Ministry of Fin. \& Cent. Bank of the Phil., The Philippines: A New Beginning, EUROMONEY, Sept. 1986, supp. at 28-29 (discussing the outflow of capital from the Philippines in the wake of the assassination of Benigno Aquino, Jr., a leading government opponent).

${ }^{80}$ WFAL I, 612 F. Supp. at 354-55. The decree also provided for sanctions should 
When the CDs matured in early December 1983, Citibank refused to repay Wells Fargo, ${ }^{81}$ claiming that it was blocked by MAAB 47. Wells Fargo filed suit shortly thereafter. ${ }^{82}$ The district court denied Wells Fargo's motion for summary judgment, ${ }^{83}$ and tried the case without a jury. ${ }^{84}$

At trial, Citibank claimed that the debt had situs in the Philippines, and thus was covered by Philippine law. ${ }^{85}$ Citibank also argued that Wells Fargo had assumed the risk of sovereign action, in exchange for an interest rate higher than was available in the United States. ${ }^{86}$ The court rejected Citibank's interpretation of the higher rate, noting that Citibank was offering the same interest rate in both "stable" and "unstable" countries. ${ }^{87}$ The court also held that Citibank was liable even if Philippine law applied, requiring Citibank to use its worldwide assets to satisfy the debt. ${ }^{88}$

a bank fail to comply. See id. at 355. While the remittance of principal was controlled, no mention was made of interest. Citibank Manila continued to pay interest on the CDs at issue. See id.

${ }^{81}$ At the time of maturity, Citibank had not filed a request with the Philippine Central Bank for permission to remit Wells Fargo's funds. See WFAL I, 612 F. Supp. at 355. Only after the suit was filed did Citibank seek permission to repay Wells Fargo. In March 1984, Citibank received permission to repay with its non-Philippine assets (i.e., branch assets not carried in a Philippine account). See id. Thereafter, Citibank paid Wells Fargo $\$ 934,000$, extinguishing $46 \%$ of its liability to Wells Fargo, see id.; WFAL II,660 F. Supp. at 947, and continued to pay the interest due on the remaining $\$ 1,066,000$, see supra note 80 .

${ }^{82}$ See WFAL V, 852 F.2d 657, 659 (2d Cir. 1988).

83 See WFAL $I, 612$ F. Supp. at 358.

84 See WFAL II, $660 \mathrm{~F}$. Supp. at 947.

85 See id.

${ }^{86}$ See id. Citibank had made the same claim in its motion for summary judgment. See WFAL I, 612 F. Supp. at 356.

${ }^{87}$ See WFAL II, 660 F. Supp. at 950 . The court also found that neither party was able to establish a custom in the Eurodollar market that would indicate where sovereign risk should fall. See id.

While the court ruled that the equality in rates across countries was indicative that investors were not being compensated for sovereign risk, another explanation is possible. Professor Herring has argued that such a phenomenon can be explained by assuming that depositors bear the risk of exchange controls, controlling their exposure by varying the size of their deposits in different locales. See Herring, supra note 46 , at 69 . While this hypothesis may explain the equivalent interest rates being offered by Citibank in Wells Fargo, it does not necessarily offer a normative solution to the problem of risk allocation. It is not clear that banks could not accomplish this same result by reinvesting the deposits they take in. Citibank Manila, for example, was able to pay $46 \%$ of the claim made by Wells Fargo by using its non-Philippine assets. See WFAL I, 612 F. Supp. at 355.

${ }^{88}$ See WFAL II, $660 \mathrm{~F}$. Supp. at 948-50. Though the court made no mention of the response to MAAB 47 by the other foreign banks in Manila, it is interesting to note that two of the other three full branches were repaying their depositors' claims 
In addition, MAAB 47 did not prohibit repayment from nonPhilippine assets. ${ }^{89}$

The Second Circuit remanded. ${ }^{90}$ In an unpublished opinion, the appellate court asked the district court to clarify whether its judgment was based on an agreement between the parties as to where the deposits were collectible (i.e., Manila or New York), or on the conclusion that Philippine law governed the case. ${ }^{91}$ The district court found that the confirmation slips established New York as the place for repayment, but did not decide as to where the funds would be collectible. ${ }^{92}$ Applying federal and New York choice of law rules, the court concluded that since the debt was repayable in New York, New York law applied. ${ }^{93}$ Under New York law, all of Citibank's assets were available for its Manila branch's liabilities. ${ }^{94}$ Citibank, North America, was liable to Wells Fargo for the full amount of the CDs.

On appeal, the Second Circuit affirmed, adopting different reasoning than did the district court. By holding that a debt may be collected wherever it is repayable the Second Circuit affirmed, as not "clearly erroneous," the lower court's finding of an agreement for repayment in New York. ${ }^{95}$ The court noted further that the lower court's conclusion that there was no agreement as to the site of collection did not change the result. ${ }^{96}$ Since the agreement named New York as the place of repayment, the situs of the debt was New York, and not Manila. ${ }^{97}$

from their non-Philippine assets. See Mendelsohn, supra note 76, at 18 . One spokesman characterized the repayments as an attempt to keep the Euromarkets "working smoothly," and noted that "Citibank [was] not very popular . . for raising these [legal] issues." Id.

${ }^{89}$ See WFAL II, $660 \mathrm{~F}$. Supp. at 948-49. This ruling also led to the failure of Citibank's impossibility claim. See id. at 950-51.

${ }^{90}$ See WFAL III, 847 F.2d 837, 837 (2d Cir. 1988).

91 See WFAL $I V, 695$ F. Supp. 1450, 1450-51 (S.D.N.Y. 1988) (explaining the Second Circuit's basis for remand).

92 See id. at $1452-53$.

${ }^{93}$ See id. at 1454. New York was the jurisdiction with the greatest interest in the suit because the transaction was denominated in U.S. dollars and was cleared through New York correspondent banks. See id. Such a holding, the court concluded, would promote consistency in financial transactions and help maintain New York's “"preeminent financial position." Id. (quoting J. Zeevi \& Sons, Ltd. v. Grindlays Bank (Uganda) Ltd., 333 N.E.2d 168, $172-73$ (N.Y. 1975)).

${ }_{94}$ See WFAL IV, 695 F. Supp. at 1454 (citing Perez v. Chase Manhattan Nat'l Bank, N.A., 463 N.E.2d 5, 7 (N.Y. 1984) (holding that the parent bank is ultimately liable for the obligations of its branch)).

${ }^{95}$ See WFAL V, 852 F.2d 657, 660 (2d Cir. 1988).

${ }^{96}$ See $i d$. at 661 .

${ }^{97}$ See id. at $660-61$. The court quite accurately stated that situs can be varied by 
The Supreme Court granted certiorari, ${ }^{98}$ but unfortunately produced an opinion that provides little guidance. With an opportunity to resolve the confusion regarding situs and its application to Eurodeposits, the Court declined to rule on the merits. ${ }^{99}$ Rather, it reversed the appellate court's opinion on the grounds that the Second Circuit relied on factual assumptions different than those used by the district court. ${ }^{100}$ The appellate court could reject the district court's findings only if it found those findings to be "clearly erroneous," as provided for by Federal Rule of Civil Procedure 52(a). ${ }^{101}$ The case was vacated and remanded by the Court. ${ }^{102}$

The Second Circuit proceeded to reaffirm the district court's opinion. ${ }^{103}$ After echoing the lower court's rhetoric concerning New York's "sreeminent financial position," 104 the court proceeded to affirm the lower court's holding, agreeing with its analysis. ${ }^{105}$ The court reiterated its conclusion that a party could collect a debt at the previously agreed place of repayment. ${ }^{106}$ In deference to the Supreme Court's opinion, the Second Circuit added that it did not disagree with the lower court's finding that there was no agreed-to collection site in the instant case. ${ }^{107}$

agreement between two parties. See id. at 660 . The court found such an agreement to exist between Wells Fargo and Citibank, and thus held situs to be in New York. Yet, nowhere in the deposit agreement is situs mentioned. See id. at 659. It is questionable that Citibank intended the term "repayment" to be read to locate situs. Since the majority of Eurodollar transactions are payable in New York, due to the use of the CHIPS system, see supra note 27 and accompanying text, the court's holding implies that most, if not all, Eurodollar transactions have situs in New York. While this holding may have some merit as a method of determining jurisdiction, it utterly fails to account for the realities of the Eurodollar market.

98 Citibank, N.A. v. Wells Fargo Asia Ltd., 493 U.S. 990 (1989).

99 It had been hoped that a definitive ruling by the Supreme Court on the merits would serve as a guide for future Eurodollar litigation. See Kassa, supra note 10, at 148.

${ }^{100}$ See WFAL VI, 495 U.S. 660, 672 (1990).

101 See id. at 670 . The most honest opinion was probably the concurrence written by Chief Justice Rehnquist. In his opinion, he criticized the granting of certiorari to the case as a waste of the Court's resources, as the opinion merely duplicated the Second Circuit's decision. See id. at 674 (Rehnquist, C.J., concurring).

${ }^{102}$ See id. at 674.

${ }^{103}$ See WFAL VII, 936 F.2d 723, 724 (2d Cir. 1991), affg 660 F. Supp. 946 (S.D.N.Y. 1987).

${ }^{104}$ Id. at 726 (quoting J. Zeevi \& Sons, Ltd. v. Grindlays Bank (Uganda) Ltd., 333 N.E.2d 168, 172-73 (N.Y. 1975)); see also supra note 93 and accompanying text.

${ }^{105}$ See WFAL VII, 936 F.2d at 727-28.

106 See id.

107 See id. at 728. The Supreme Court declined to review the Second Circuit's 
After seven years of litigation, no consistent principle can be drawn from Wells Fargo v. Citibank, N.A. The opinions were highly fact-specific-no broad overview of the special legal nature of the Eurodollar market was made. While a narrow ruling might be more consistent with good jurisprudence, it does little to solve the problems of other Euromarket participants.

\section{B. The Mexican Cases}

The situations presented in Braka v. Bancomer, S.A., ${ }^{108}$ and Callejo v. Bancomer, S.A., ${ }^{109}$ are far removed from the high finance of Wells Fargo. While Wells Fargo involved an interbank transaction between two financial institutions, ${ }^{110}$ the Mexican cases dealt with individual depositors in the United States doing business with the same Mexican bank.

The two cases are factually similar. ${ }^{111}$ Both plaintiffs were U.S. citizens who purchased CDs from Bancomer's Mexico City office between late 1981 and early 1982, with maturities ranging from six months to one year. ${ }^{112}$ The interest rate payable on the CDs ranged from $14.3 \%$ to $23.25 \%{ }^{113}$

In the late summer of 1982, Mexico began to experience a harsh economic downturn. ${ }^{114}$ Oil, Mexico's main foreign exchange producer, was dropping in price, and Mexico was faced with a shortage of foreign exchange. ${ }^{115}$ In response, the Mexican government issued exchange control decrees, ${ }^{116}$ which had the effect

opinion. See Citibank, N.A. v. Wells Fargo Asia Ltd., 112 S. Ct. 2990 (1992).

108589 F. Supp. 1465 (S.D.N.Y. 1984), affd, 762 F.2d 222 (2d Cir. 1985).

109764 F.2d 1101 (5th Cir. 1985).

110 See supra notes 76-77 and accompanying text.

111 Smedresman and Lowenfeld have also classified these two cases as being quite similar and treat them together in their article on the Euromarket. See Smedresman \& Lowenfeld, supra note 21, at 783-86 (discussing judicial approaches taken in the Mexican cases).

112 See Callejo, 764 F.2d at 1105-06; Braka, 589 F. Supp. at 1466. In Braka, the CDs totaled $\$ 2.1$ million. See id. Those in Callejo totaled approximately $\$ 300,000$. See Callejo, 764 F.2d at 1106.

113 See Braka, 589 F. Supp. at 1466. The Braka court speculated that these "relatively high" interest rates were paid in order to attract U.S. investors. See id. at 1471. While the court in Callejo failed to mention the interest rates payable on the plaintiffs' CDs, plausibly the rates were similar, given the similar duration, time period, and the fact that they were issued from the same bank. See Callejo, 764 F.2d at 1105-06.

114 See Braka, 589 F. Supp. at 1467.

115 See id.

116 See id.; Pando, supra note 5, at 310-11. 
of drastically reducing the value of the CDs. ${ }^{117}$ Nationalization of Mexico's banking system followed shortly thereafter. ${ }^{118}$

Summary judgment was granted to Bancomer in Braka. ${ }^{119}$ On appeal, the Second Circuit affirmed the district court's opinion. ${ }^{120}$ It held that the CDs, which named Mexico City as the place of repayment, had situs in Mexico. ${ }^{121}$ Bancomer's actions were valid under the Mexican exchange controls, and thus could not be ruled a breach. ${ }^{122}$

The Callejo litigation followed much the same course. Though it disagreed with the lower court's reasoning, the Fifth Circuit affirmed the dismissal of the case. ${ }^{123}$ Applying the incidents of the debt analysis, the court found that situs for the CDs was in Mexico. ${ }^{124}$ As in Braka, Bancomer was held to have complied with Mexican law, and was relieved of any further obligation. ${ }^{125}$

The Mexican cases present a fact pattern very different from that in Wells Fargo. Neither Braka nor Callejo were banking institutions; they were individual depositors. The only similarity between these depositors and Wells Fargo is that they had deposited money in a bank. The differentiation between place of collection and place of repayment, seemingly so important in Wells Fargo, ${ }^{126}$ was not even made an issue in the Mexican cases. Viewed as a group, Wells Fargo, Braka, and Callejo are emblematic of the fog of

${ }^{117}$ See supra note 6 and accompanying text.

${ }^{118}$ See Braka, 589 F. Supp. at 1467.

119 See id. at 1474 .

${ }^{120}$ See Braka v. Bancomer, S.N.C., 762 F.2d 222, 224 (2d Cir. 1985), affg 589 F. Supp. 1465 (S.D.N.Y. 1984).

121 See id. at 224-25. The court explained that the CDs had "come to complete fruition" within Mexico. Id. at 224 (quoting Allied Bank Int'l v. Banco Credito Agricola de Cartago, 757 F.2d 516, 521 (2d Cir.), cert. dismissed, 473 U.S. 634 (1985)); see also supra notes 64-69 and accompanying text (discussing the complete fruition test). Situs in Mexico was contractually mandated. See Braka, 762 F.2d at 224-25; cf. Garcia v. Chase Manhattan Bank, N.A., 735 F.2d 645, 650-51 (2d Cir. 1984) (parties agreed to repayment at any Chase Manhattan branch worldwide, thus nullifying the need for a situs determination).

122 See Braka, 762 F.2d at 225-26.

123 The district court had dismissed the suit on jurisdictional grounds. See Callejo v. Bancomer, 764 F.2d 1101, 1104-05 (5th Cir. 1985).

124 See id. at 1123-24. The court identified the factors relevant to its decision as "the place where the deposit is carried, ... . the place of payment, the intent of the parties . . . , and the involvement of the American banking system . . . . Id. at 1123; see supra notes 70-73 and accompanying text (discussing incidents of the debt analysis).

${ }^{125}$ See Callejo, 764 F.2d at 1125.

${ }^{126}$ See supra text accompanying note 92. 
confusion that hangs over this area of the law. A more consistent result can be obtained if the relationship between a depositor and a bank is analyzed in risk allocation terms, not in terms of where a deposit is located.

\section{Allocating Risk AND Grafting a RULE}

In legal terms, a Eurodeposit must be interpreted as a contract between a depositor and a bank. ${ }^{127}$ As such, the allocation of risk and responsibility between the two parties is allocated by the terms of the deposit agreement. ${ }^{128}$ Law and economics principles can give insight into this allocation process with more intellectual coherence than the various situs rules. ${ }^{129}$ These principles can then be used in forming a rule of risk allocation.

\section{A. The Coase Theorem}

The Coase Theorem, developed by Ronald $H$. Coase in his seminal 1960 article, ${ }^{130}$ is the starting point for analyzing the depositor/bank relationship. The Theorem posits that, in a zero transaction cost ${ }^{131}$ ("ZTC") world, the efficient outcome will occur $^{132}$ regardless of the initial allocation of rights. ${ }^{133}$

127 See Smedresman \& Lowenfeld, supra note 21, at 739.

${ }^{128}$ See Charles O. Hardy, Risk and Risk-Bearing, in ECONOMICS OF CONTRACT LAW 27 (Anthony T. Kronman \& Richard A. Posner eds., 1979) (discussing general principles of risk allocation).

${ }^{129}$ See supra notes 47-75 and accompanying text (discussing various situs tests).

${ }^{130}$ See Ronald H. Coase, The Problem of Social Cost, 3 J.L. \& ECON. 1, 10 (1960). Posner describes the Coase Theorem as "establish[ing] a framework for analyzing the assignment of property rights and liability in economic terms." POSNER, supra note 14, at 20; see also POLINSKY, supra note 14, at 11 (explaining general principles of the Coase Theorem). For a description of the Coase Theorem, see Robert Cooter, The Coase Theorem, in 1 THE NEW PALgRAVE: A Dictionary of Economics 457, 457-60 (John Eatwell et al. eds., 1987).

Prior to Coase's article, economic principles had been applied chiefly in antitrust litigation. See POSNER, supra note 14, at 19. The so-called "new" law and economics sweeps much broader, attempting to cover areas as diverse as nuisance, criminal, and family law. See id. at 19-20.

131 Zero transaction costs describes a transaction in which two or more parties can come together and negotiate costlessly. See PoLINSKY, supra note 14, at 12 . In the real world-outside the economic model-transaction costs are never zero. See POSNER, supra note 14, at 45 (noting that excessive costs may make transacting uneconomical). Nevertheless, the Eurodollar market, given its size, its highly advanced communications network, and its two-party nature (one depositor deals with one bank), comes close to the ideal. See infra notes $141-45$ and accompanying text.

132 The efficient outcome is the one that is Pareto optimal, or at least Pareto superior to all other outcomes. See ROBERT COOTER \& THOMAS ULEN, LAW AND 
A simple example illustrates this principle. ${ }^{134}$ Suppose a railroad track lies next to a farmer's fields. Passing trains produce sparks, which burn the farmer's crops. ${ }^{135}$ The railroad company could decrease the damage by running its trains slower, or by installing spark arresters. Alternatively, the farmer could decrease the damage by leaving part of his land fallow, avoiding the sparks completely.

Assuming a ZTC world, ${ }^{136}$ the party with the greater economic interest will buy out the other party. If the gain to the railroad from running trains faster or avoiding the installation of arresters is greater than the farmer's loss, the railroad will pay the farmer to keep his land fallow. ${ }^{137}$ If the crops are more valuable than the added cost of decreasing the sparks, the farmer will pay the railroad. In either case, the efficient outcome will result-the only bargaining is over the division of the economic gain. ${ }^{138}$

ECONOMICS 49 (1988). Pareto optimality is that allocation of resources where no person can be made better off without making another worse off. See id. A Pareto superior choice makes all parties better off than does a Pareto inferior choice (i.e., it comes closer to Pareto optimality). See id.

A more relaxed version of efficiency is the Kaldor-Hicks standard. See POSNER, supra note 14, at 13. Kaldor-Hicks efficiency is an allocation that increases total benefit without regard to the distributional effect-one party's position is improved by more than another party's position is worsened. See id. Theoretically, the winners can pay off the losers, achieving Pareto superiority. See COOTER \& ULEN, supra at 51; Jules L. Coleman, Efficiency, Utility, and Wealth Maximization, 8 HOFSTRA L. REV. 509, 513-14 (1980).

133 See POLINSKY, supra note 14, at 12; POSNER, supra note 14, at 7.

134 The following example is drawn from Coase's original article. See Coase, supra note 130, at 30-34. Coase drew this example from the English common law, specifically Vaughan v. Taff Vale Ry., 137 Eng. Rep. 667 (Ex. 1858), rev'd, 157 Eng. Rep. 1351 (Ex. Ch. 1860). For a recent treatment of this example, see PosNER, supra note 14 , at 7 .

135 One might conclude that the railroad is at fault, since it is burning the crops. But there would have been no loss if the crops had never been planted. In a general sense, both parties are causing the damage. See Coase, supra note 130, at 2 (describing the reciprocal nature of nuisance problems). Coase argues that the correct question to ask is whether we should allow A to harm B or B to harm A? See id.

136 The major transaction costs in this problem are the bargaining costs of bringing together the single railroad company with the potential multitude of farmers who have land bordering the right of way. For another example of how transaction costs are important, see PoLINSKY, supra note 14, at 12-13.

137 See POSNER, supra note 14, at 7.

138 If, for example, the railroad will buy out the farmer, the farmer will wish to appropriate some of the railroad's anticipated gain for himself. This behavior, known as "strategic bargaining," can be a major transaction cost. See PoliNskY supra note 14, at 18-19; POSNER, supra note 14, at 54-55. 
The Coase Theorem is also applicable in a positive transaction cost world. Parties will transact as long as the benefit derived outweighs the transaction costs. ${ }^{139}$ Any legal rule in a positive transaction cost world should seek to minimize such costs so that parties can fruitfully transact. ${ }^{140}$

\section{B. Transaction Costs in the Eurodollar Market}

The Eurodollar market, although not a ZTC environment, comes closer to the Coasian ideal than do other markets. It is a large market with an ample number of players. ${ }^{141}$ With the amount of money being transferred, especially in the interbank market, there is no danger that a transaction will not occur because of insufficient resources. ${ }^{142}$

The communication between market members is rapid, with information being widely disseminated. ${ }^{143}$ Bargaining is infor-

${ }^{139}$ See, e.g., POLINSKY, supra note 14 , at $12-13$ (arguing that positive transaction costs may lead to inefficient results due to the failure to bargain). Transaction costs can include the costs of gathering information, identifying parties, bargaining, and enforcing a bargain. See COOTER \& ULEN, supra note 132, at 100-02. If information is distributed asymmetrically, the efficient outcome might be unattainable. It is possible that the party with the information may seek to maximize its own return by not dealing and avoiding further transaction costs. See id.

Another problem is the asymmetrical distribution of wealth. If the value of an entitlement forms a large portion of one party's wealth, that party may be unable to acquire the resources needed to purchase that entitlement, even if the party values the entitlement higher than does the opposing party. See POSNER, supra note 14, at 15,43 n.1.

140 See POSNER, supra note 14, at 505-06. Posner believes that judges act efficiently when issuing their opinions, even if they are unaware that they are doing so. See id. at 511-12.

${ }^{141}$ See supra text accompanying note 21 . Because the dollar accounts for $60 \%$ of the market, it provides the largest market. See supra note 3. A large market will minimize the danger of strategic bargaining. When a party knows that its opposite can easily transact with a third party, there is less incentive to engage in strategic bargaining. Cf. Boomer v. Atlantic Cement Co., 257 N.E.2d 870 (N.Y. 1970) (plaintiffs could bargain strategically with defendant cement plant and among themselves since an agreement with everyone was needed).

142 See supra note 139 (discussing the problem with the Theorem when one party lacks resources). In the interbank market, it is unlikely that a party will be unable to place or accept a deposit because of insufficient funds.

143 See DEAK \& CELUSAK, supra note 2, at 170-71. Banks have access to a number of wire services that serve to provide them with large amounts of information on global markets. See SARVER, supra note 18, at $341,344-46$. At a cost of roughly $\$ 700$, plus communications charges, a client of American Telerate has access to 60,000 pages of financial information. See id. at 345-46.

However, a branch that is in-country could be presumed to have an information edge on the particular social and governmental conditions within that country. See 
mal-witness the simple documentation exchanged in the Wells Fargo case. ${ }^{144}$ Overall, the market does come close to being perfect. Theoretically, there need be no rule dealing with the allocation of exchange control risk-the parties will always be able to allocate it between themselves. ${ }^{145}$ The cases discussed evince that this is not the current situation.

\section{The Superior Risk Bearer}

If a legal rule must be imposed, it should target the superior risk bearer and assign the risk to that party, ${ }^{146}$ who then becomes the insurer of that risk. The goal should be to find the cheaper insurer. ${ }^{147}$ Posner defines the cheaper insurer as the party that can minimize measurement costs $^{148}$ as well as transaction

infra notes 160-61 and accompanying text (discussing advantage of in-country banks in assessing risk).

144 See supra note 77 and accompanying text (discussing the telexes and confirmation slips exchanged in Wells Fargo).

145 See Coase, supra note 130, at 10. Even if there is an allocation, it may not be provable. Wells Fargo is an example of an allocation that was not clear on its face. Citibank argued that the depositor had been allocated the risk, see WFAL $I, 612 \mathrm{~F}$. Supp. 351, 353 (S.D.N.Y. 1985), but the exchange of telexes that constituted the deposit agreement made no mention of any such allocation, see id. at 354 , and Citibank's statement of Terms and Conditions disclaiming responsibility, see id., was not sufficient to avoid bearing the loss. A rule allocating the risk to one party would avoid such uncertainty.

${ }^{146}$ See POLINSKY, supra note 14, at 53-54 (discussing the partner-associate relationship in a law firm as an example of proper risk allocation).

${ }^{147}$ The cheaper insurer will be the party best able to bear the risk. See id. at 56; POSNER, supra note 14, at 93. Posner differentiates between preventable and unpreventable risks. Preventable risks should be assigned to the party best able to prevent. See id. at 91. Unpreventable risks should be assigned to the cheaper insurer. See id. at 93.

For a further discussion of the relation between information, risk, and insurance, see COOTER \& ULEN, supra note 132, at 55-70; DAvid A. LEREAH, INSURANCE MARKETS: INFORMATION PROBLEMS AND REGULATION (1985).

148 Measurement costs are composed of the costs of estimating the probability that the loss will occur and the magnitude of the loss if it does occur. See POSNER, supra note 14, at 93 . In the Eurodollar context, the magnitude determination is easy-it equals the deposit at risk. As to the determination of the probability of exchange controls, several models are available to assist in quantifying the risk. See HaNS

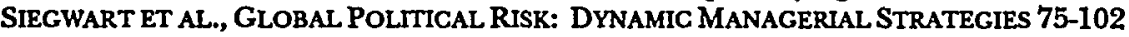
(1989); Robert O. Slater, The Bootstrapping Approach: An Alternative to Old Methods Restyled, in AsSEssing CORPORATE POLITICAL RISK: A GUIDE FOR INTERNATIONAL BUSINESSMEN 149, 149-62 (David M. Raddock ed., 1986). 
costs. ${ }^{149}$ Identifying these costs is best done by the party with more information. ${ }^{150}$

Additionally, the risk bearer should be the party that is closest to risk-neutral. ${ }^{151}$ The risk-neutral party can accurately price a risk without being swayed by bias towards the "sure thing." A deep pocket is also an advantage for the risk-neutral party-if too large a percentage of the party's wealth is at issue, bias may creep in..$^{152}$

\section{Crafting a Rule}

The search for an efficient rule that will deal with exchange control risk must begin with finding the cheaper insurer in the Eurodollar market-we cannot assume that parties in the market will efficiently (and explicitly) allocate the risk among themselves. ${ }^{153}$ Imposing a rule has the benefit of producing certainty in the market, one of the chief policy concerns of the courts that ruled on the Wells Fargo litigation. ${ }^{154}$ After finding a rule, its usefulness

149 See POSNER, supra note 14 , at 93 (noting that transaction costs consist principally of the cost associated with pooling risks in order to reduce the overall risk exposure).

150 See id.

${ }^{151}$ See PolinSKY, supra note 14, at 55-56. A risk-neutral party is ambivalent to the variability of a return. See id. at 53. A risk-averse party avoids uncertainty, and thus is willing to accept a lower return if that return is certain. See id. at 53-54.

For example, consider a coin flip, with a prize of $\$ 1000$ if the correct side is chosen. The probability of either side coming up is $50 \%$. Thus, the expected return is $\$ 500$ ( $\$ 1000$ multiplied by .50$)$. A risk-neutral party would accept the contest and only relinquish the opportunity if it is paid $\$ 500$ (or more). In contrast, a risk-averse individual would rather accept a lower sum, say $\$ 400$, than risk getting nothing. See POSNER, supra note 14, at 11-12.

152 See POSNER, supra note 14, at 15 (discussing the Wells Fargo case).

153 A basic assumption of the Coase Theorem is a perfect market, with zero transaction costs. See supra notes 131-32 and accompanying text. Even the Eurodollar market does not meet this ideal. In a world of positive transaction costs and asymmetric information, the efficient result may not always occur. This does not mean that the Coase Theorem is inapplicable. Rather, given a positive transaction cost world, the risk should be allocated to the party that most likely would have accepted the risk in a world of zero transaction costs. This is the concept of the cheaper insurer. See POSNER, supra note 14, at 93.

Even if the efficient allocation does occur, it may not be done explicitly, leading to the uncertainty that gives rise to litigation. See supra note 145 .

154 See supra notes 93 \& 104 and accompanying text. Imposition of such a rule, whether by judicial or congressional action, would serve to preempt state choice-oflaw doctrine, creating a federal rule. Given the international nature of the Eurodollar market, this is a valid exercise of federal power. See Michael H. Gottesman, Draining the Dismal Swamp: The Case for Federal Choice of Law Statutes, 80 GEO. L.J. 1, 23-28 (1991); see also Daniel C.K. Chow, Limiting Erie in a New Age of International Law: Toward a Federal Common Law of International Choice of Law, 74 IOWA L. REV. 165, 220- 
can be tested by applying it to the previously discussed cases, and examining the results.

\section{Who is the Cheaper Insurer?}

Between depositor and bank, it is not readily apparent which party is better positioned to accept the risk, especially in the interbank market. ${ }^{155}$ The cheaper insurer is the one best situated to price the risk, which involves setting the risk premium to be charged on the account. ${ }^{156}$ Given the requisites of the cheaper insurer, ${ }^{157}$ the bank is in the better position to bear the risk of foreign exchange control. ${ }^{158}$

Much of what makes the bank the better risk bearer is inconclusive when both parties are banks. While banks are more risk-neutral than individual depositors, ${ }^{159}$ there is nothing that makes one bank inherently more risk-neutral than another. Similarly, one bank is probably as much of a deep pocket as the other.

Banks accepting deposits are in a better position to assess the magnitude of sovereign risk than are their depositors, be they individuals or other financial institutions. ${ }^{160}$ An in-country bank

24 (1988) (discussing the advantages of a federal common law of international choiceof-law).

${ }^{155}$ See supra notes 23-25 (discussing the interbank market).

156 See supra note $\mathbf{3 9}$ and accompanying text.

157 See supra notes $146-52$ and accompanying text.

158 Such an allocation also has the benefit of forcing the country imposing controls to bear the cost of its controls. If banks are liable for controls imposed by a country, they will be much more circumspect in evaluating the suitability of a given locale for a branch office. Without such liability, expansion into riskier countries is more likely. The loss of foreign banks, and the business they bring, will enter into the calculus of countries contemplating the imposition of controls. $C f$. Gerstenhaber, supra note 16, at 2379-83 (arguing that allocating the risk of U.S. freeze orders to depositors would force the United States to internalize the costs of such orders).

${ }_{159}$ As a corporation, a bank is likely to be less risk averse than an individual since the bank owners, its shareholders, have limited liability and can compensate for any risk the bank incurs by diversifying their portfolios. See POSNER, supra note 14, at 370-71.

${ }^{160}$ See Irving S. Friedman, Evaluation of Risk in Intermational Lending: A Lender's Perspective, in KEY IssuEs IN INTERNATIONAL BANRING 115, 119-21 (1977) (stressing the importance to a bank of evaluating the risks of the country in which it is situated). Interestingly, Mr. Friedman was Senior Vice President and Senior Adviser for International Operations at Citicorp, Citibank Manila's parent company, at the time he wrote his article. See id. at 115.

This position contrasts with that taken by Gerstenhaber concerning depositors at risk of becoming targets of a U.S. freeze order. See Gerstenhaber, supra note 16, at 2377. It may well be that the "violent political groups" that trigger the imposition of freezes may have some special relationship with the states against which freezes are 
is probably more in tune with the political and economic situation in its country than are its depositors. Its officers will have more contact with the country's government through their dealings with regulators and officials. Citibank Manila, for example, probably understood the implications of the political unrest in the Philippines in the summer of 1983, well before the Philippine government imposed the exchange controls of October 1983.161

Specialization is also at work here. It is cheaper for one bank to monitor the events in a country, and set its interest rates accordingly, than for one hundred depositors to monitor those same events, and negotiate individually with the bank. An in-country bank can put in place the monitoring apparatus that will keep it informed as to developments within the country.

Going beyond the question of the cheaper insurer, there is also an equity issue that argues in favor of assigning the risk to the bank. Such issues can be considered if the market is efficient, which allows a depositor receiving an entitlement to sell it off if she so desires. ${ }^{162}$ Though the equities in the interbank situation are not clear, in cases with smaller depositors it seems fairer to place the burden on the bank, barring any explicit allocation. ${ }^{163}$

directed. See id. But this would not appear to be the case in the Eurodollar market in general. The controls at issue in Wells Fargo, Braka, and Callejo were not directed at any particular depositor. See supra notes 76-126 and accompanying text. There was no reason why Wells Fargo Asia Ltd. or Messrs. Braka and Callejo would have known more about Philippine or Mexican policies than the banks that accepted their deposits.

${ }^{161}$ Citibank Manila was aware of forthcoming Philippine action according to bankers interviewed in a Wall Street Journal article appearing in early 1984. See S. Karene Witcher, Wells Fargo Sues Citibank Over Manila Deposits, WALL ST. J., Feb. 23, 1984, at 40 . The bankers alleged that Citibank sought to diminish its exposure in Manila by replacing interoffice deposits (i.e., money deposited in Manila from other Citibank offices in the world) with funds raised in the interbank market. See id. To support this allegation, they observed that Citibank had been "very aggressive" in the interbank market, paying a premium of as much as three fourths of a percent in the summer of 1984. See id. The bankers also referred to a confidential report from the Philippines central bank that indicated Citibank was replacing its internal funds with the monies acquired on the interbank market. See id.

162 See Herbert Hovenkamp, Marginal Utility and the Coase Theorem, 75 CORNELL L. REV. 783, 809 (1990) ( ${ }^{u}[1]$ f markets are working well, entitlements may be assigned on the basis of fairness or justice, or some similar criteria unrelated to economic efficiency. The allocatively efficient solution will emerge nonetheless."). Thus, the efficiency of the Eurodollar market allows one to look beyond efficiency.

163 See, e.g., Vishipco Line v. Chase Manhattan Bank, N.A., 660 F.2d 854, 863 (2d Cir. 1981) ("U.S. banks, by operating abroad through branches, reassure foreign depositors that their deposits will be safer with them than they would be in a locally incorporated bank") (citing Heininger, supra note 58, at 911-12); Andy McCue, 
Any assignment of risk to banks, however, must remain alienable. ${ }^{164}$ Assuming for the moment that any rule would apply only to U.S. banks, the effect would be a reduction in the rates U.S. banks offer their depositors. As insurers, the banks would have to discount their interest rates by the amount at which they value the risk of exchange controls. ${ }^{165}$ Faced with lower rates, some depositors might opt to self-insure, instead of accepting the banks' "insurance." Others might value the risk at a lower level than the U.S. banks and seek alternative investments. The result would most likely be a drop in U.S. bank deposits. ${ }^{166}$

To avoid such a destructive effect on the competitiveness of U.S. banks, any rule of allocation must allow banks to contract away the risk. ${ }^{167}$ Banks would offer depositors a higher rate if the depositors assumed the risk. Thus, a two-tiered rate structure would develop. The lower rate would allocate the risk to the bank; the higher, to the depositor. ${ }^{168}$

Such an arrangement would quickly begin to respond to market forces. ${ }^{169}$ The spread between the two rates would initially be set by the bank. As market participants analyzed this spread, they would form a decision as to its correctness. If the bank was underpricing the risk, funds would flow to the lower, guaranteed rate. Conversely, overpricing the risk would result in funds flowing

Citibank Freezes Dollar Deposits in Philippines, WALL ST. J., Jan. 24, 1984, at 37 (quoting a Japanese banker as "argu[ing] that 'someone as big as Citibank should honor its obligations'").

${ }_{164}$ See Guido Calabresi \& A. Douglas Melamed, Property Rules, Liability Rules, and Inalienability: One View of the Cathedral, 85 HaRv. L. REV. 1089, 1111-15 (1972) (discussing inalienable entitlements). The present state of regulation over the U.S. banking industry already functions as an impediment vis-a-vis the banks of other industrialized countries. See Cane \& Barclay, supra note 29, at 315-319. Creating an inalienable entitlement to the benefit of depositors may act to further weaken the competitive position of U.S. banks. Depositors that do want to assume the risk will go to other banks.

${ }^{165}$ A similar pricing mechanism is used to account for the added burdens of U.S. regulations on deposits held in the U.S. See supra notes 29-38 and accompanying text (discussing U.S. regulation of domestic deposits).

166 The failure to bear the risk of exchange controls, barring an explicit reallocation to depositors, may also lead to a drop in deposits. See McCue, supra note 163, at 37 (noting that some bankers responded to Citibank Manila's actions by withdrawing funds from other Citibank branches around the world).

167 The courts in Braka and Callejo concluded that such a risk transfer from Bancomer to its customers had occurred. See cases discussed supra notes 108-25 and accompanying text.

168 This higher rate would be the "bribe" that banks would have to pay depositors to accept the sovereign risk. See Gerstenhaber, supra note 16, at 2374-75.

${ }^{169}$ See supra text accompanying note 43 (discussing arbitrage). 
to the higher rate. The interactions between the rates set by each bank would produce a market-clearing spread, where each depositor, guided by her individual preferences, would allocate her funds between guaranteed and non-guaranteed accounts. ${ }^{170}$

Essential to the proper functioning of this system is judicial acceptance of risk transfer. When the parties know they are allocating a risk ex ante, and they specify their agreement in writing, courts should be ready to accept their wishes. At times, courts have been reluctant to enforce such risk allocation clauses. ${ }^{171}$

The net effect of the proposed rule is to create a default setting for deposit relationships that do not explicitly speak to the allocation of exchange control risk. By creating the default rule, we can dispense with the doctrine of situs. A bank accepting Eurodollar deposits bears the risk, unless it explicitly assigns that risk to the depositors.

\section{Applying the Rule}

Applying this rule of risk allocation ex post is a difficult matter. Above all, the rule is forward looking. Once parties know the rule and recognize the risk, cases like Wells Fargo, Callejo, and Braka should disappear, or at the very least become easier to resolve. Probably the strongest argument that the outcomes were correct in all three cases is that the interest rates truly reflected the implicit risk allocation. In Wells Fargo, Citibank was offering one rate worldwide, irrespective of the relative instabilities of the countries in which it operated. ${ }^{172}$ The lower court in Braka found the

170 This assumes that depositors are sophisticated enough to understand the difference between the two accounts.

${ }^{171}$ See, e.g., Trinh v. Gitibank, N.A., 850 F.2d 1164, 1166, 1168 (6th Cir. 1988) (declining to enforce a fairly specific clause allocating political risk to depositors). Quite often, such risk allocation clauses are contained in standard form contracts, which are often criticized as resulting from unequal bargaining power. See POSNER, supra note 14, at 102-03. However, if a two-tiered interest rate structure develops, the need to negotiate over risk allocation disappears. A bank would simply have two form contracts, and would use the one corresponding to the depositor's desired risk allocation-evidenced by the rate the depositor selects. Thus, these form contracts would merely memorialize the risk allocation made when the depositor chooses whether or not to be protected.

172 See supra text accompanying note 87. It is possible that Citibank was internalizing any costs related with country risk. Citibank may have believed that it was sufficiently diversified to the point that it did not need to set different prices. The signal Citibank was sending to the other market participants by pricing Manila and London at the same rate indicated that the two markets were "equivalent," which, of course, they were not. But see Herring, supra note 46, at 69 (offering a different 
"relatively high" interest rates offered by Bancomer to be compensation for the greater risk associated with investing in Mexico. ${ }^{173}$ So it is possible that this incongruous result-Wells Fargo wins, Braka and Callejo lose-is the correct one. Between Bancomer and its individual customers, Bancomer should bear the cost, unless there is an explicit reallocation. Between Wells Fargo and Citibank, it is a toss-up. Either could equitably bear the risk of foreign exchange control. The difference is that Braka and Callejo "sold" their entitlement to Bancomer.

\section{CONCLUSION}

A move away from situs, towards a more explicit recognition of what goes on in a Eurocurrency transaction, would help promote the certainty necessary for prosperous commerce. Only by recognizing the risk that is being transferred, and basing our rules on that transfer, can we derive a logically coherent doctrine. The situs rules, grounded as they are in territoriality, do not respond to the realities of the Eurodollar market. Regarding the risk of exchange controls on Eurodeposits, the superior risk bearer, the bank, should bear the risk, barring any duly negotiated reallocation to the depositor. Such a default setting would promote the certainty necessary for a smoothly functioning system, while simulataneously protecting the smaller depositor.

rationale for the equivalent interest rates); supra note 87 (discussing Professor Herring's position).

173 See supra note 113. Apparently, the Braka court did not consider that the premium might have been the result of the cost savings realized by branches operating outside the United States. See supra notes 29-38 (discussing U.S. regulations). 
